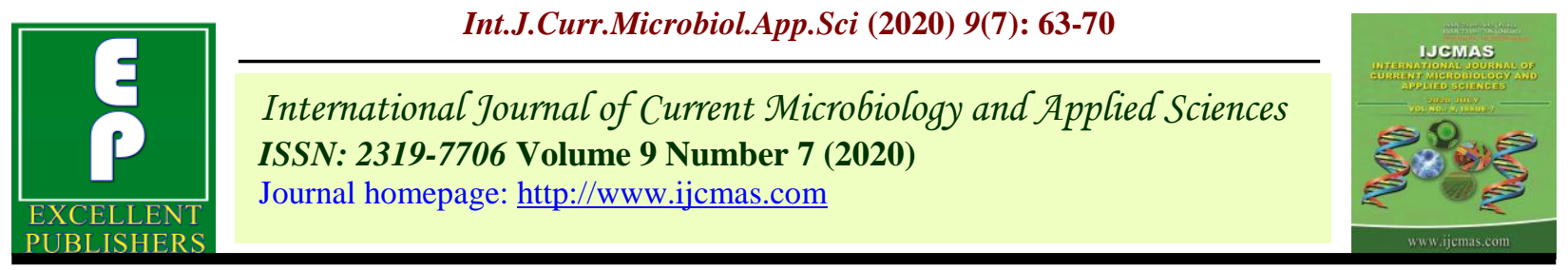

Original Research Article

https://doi.org/10.20546/ijcmas.2020.907.007

\title{
Effect of Post Emergence Herbicide on Growth, Yield and Economics of Transplanted Rice (Oryza sativa L.)
}

\author{
M. Tejaswini ${ }^{1 *}$, A. S. Halepyati ${ }^{1}$, S. Manoranjan ${ }^{2}$, B. M. Chittapur ${ }^{1}$ and N. Ananda ${ }^{1}$ \\ ${ }^{1}$ Department of Agronomy, College of Agriculture, UAS, Raichur - 584104 Karnataka, India \\ ${ }^{2}$ Division of genetics, ICAR-IARI, New Delhi-110012, India \\ *Corresponding author
}

\begin{abstract}
A B S T R A C T
\end{abstract}
A field experiment was conducted during Kharif- 2018 at Agricultural Research Station, Gangavathi, University of Agricultural Sciences, Raichur, Karnataka to study the effect of weed control practices on growth, yield and economics of

Keywords

Transplantedrice,

Hand weeding,

Herbicides, Growth and yield

Article Info

Accepted:

05 June 2020

Available Online:

10 July 2020 transplanted rice. The soil was medium deep black clay with medium fertility. The results of this experiment revealed that hand weeding twice (15 and 45 DAT) recorded significantly higher growth parameters of rice viz. number of tillers $\mathrm{m}^{-2}$, LAI and total dry mater production plant ${ }^{-1}(323.00,1.40$ and $68.71 \mathrm{~g}$, respectively) as compared to weedy check (212.67, 0.24 and $40.92 \mathrm{~g}$, respectively). The highest grain and straw yields were recorded with hand weeding twice at 15 and 45 DAT (5415 and $5783 \mathrm{~kg} \mathrm{ha}^{-1}$, respectively) followed by application of pendimethalin $38.7 \%$ CS @ $680 \mathrm{~g}$ a.i/ha as PE $f b$ bispyribac sodium $10 \%$ SC @ $25 \mathrm{~g}$ a.i/ha (4990 kg ha ${ }^{-1}$ and $5433 \mathrm{~kg} \mathrm{ha}^{-1}$ )and bispyribac sodium 2\%+2,4-D sodium salt $54.3 \%$ SP @ (25+678.75) g a.i/ha with adjuvant @ $625 \mathrm{ml} / \mathrm{ha}(4922$ and $5372 \mathrm{~kg}$ $\mathrm{ha}^{-1}$, respectively). The benefit cost ratio was significantly higher with bispyribac sodium 2\%+2,4-D sodium salt 54.3\% SP @ (25+678.75) g a.i/ha with adjuvant @ $625 \mathrm{ml} / \mathrm{ha}(2.62)$ as compared to weed free check (2.47).

\section{Introduction}

Rice (Oryza sativa L.) is one of the predominant food crops of the world. It is widely grown in tropical and subtropical regions. According to IRRI, rice is the staple food of more than three billion people in the world, most of who live in Asia. Worldwide rice is grown on an area of 163 million hectare with a production of 741 million tons and with an average productivity of 4.56 tons $\mathrm{ha}^{-1}$. In India, it is grown on nearly 43.39 million hectares with the production of 104.32 million tons triggering productivity of 2404 $\mathrm{kg} \mathrm{ha}^{-1}$. In Karnataka, rice covers 1.06 million hectares area with an annual production of 2.7 million tons but the average productivity is $2547 \mathrm{~kg} \mathrm{ha}^{-1}$ (Anon., 2018). Tunga Bhadra 
command in Karnataka state in India is an important rice growing belt covering 3.5 Lakh ha. Traditional transplanting is the major method of crop establishment in the command area. Weed infestation is the major threat to productivity of transplanted rice. Globally, actual rice yield losses due to pests have been estimated at 40 per cent out of which weeds account for 33 per cent. In India, unchecked weed competition causes yield losses to the tune of 50-65 per cent in rice. Weeds by the virtue of their high adaptability and faster growth dominate the crop habitat and reduce the yield potential of the crop. The problem of extensive weed incidence during early stages of rice crop growth cannot be determined which competes with crop plants for moisture, nutrients, light, space and other growth factors. This crop competition leads to significant yield losses to the tune of 35-55 per cent in transplanted rice. Traditionally weed control in rice is done by manual and mechanical means which are most effective and common methods but they are tedious, costly, time taking and are difficult due to continuous rains during Kharif season. Besides, adequate labourers are also not available during critical period of crop weed competition. These weeds could be controlled through chemical methods. Sometimes, application of pre-emergence herbicides also is not sufficient to give effective weed control for keeping weeds population up to threshold level. Under such situation post-emergence herbicides remains only the viable option for weed control in transplanted rice. Preemergence herbicides are most commonly used against grassy weeds in transplanted rice. But post-emergence herbicides are becoming need of the day due to emergence of weeds at later growth stages of crop. Control of weeds by herbicides is although quite effective but needs proper skill and fidelity. The choice of suitable herbicide is a major problem in many cases. Keeping above facts in views, there is a need to know the effect of post emergence herbicide on growth, yield and economics of transplanted rice (Oryza sativa L.).

\section{Materials and Methods}

Field experiment was conducted during Kharif, 2018 Agricultural Research Station, Gangavathi, Karnataka, situated at an altitude of $406 \mathrm{~m}(1,332 \mathrm{ft})$ above mean sea level at $15.43^{\circ} \mathrm{N}$ latitude and $76.53^{\circ} \mathrm{E}$ longitude and is located in the Northern Dry Zone of Karnataka. The experiment was laid out in a Randomized Block Design with 12 treatments, replicated three times. The treatments consisted of post emergence herbicides viz., bispyribac sodium $2 \%+2,4-\mathrm{D}$ sodium salt $54.3 \%$ SP @ $(20+543)$ g a.i/ha $\left(\mathrm{T}_{1}\right)$, bispyribac sodium $2 \%+2,4-\mathrm{D}$ sodium salt 54.3\% SP @ (25+678.75) g a.i/ha $\left(\mathrm{T}_{2}\right)$, bispyribac sodium $2 \%+2,4-\mathrm{D}$ sodium salt $54.3 \%$ SP @ $(30+814.5)$ g a.i/ha $\left(\mathrm{T}_{3}\right)$, bispyribac sodium $2 \%+2,4-\mathrm{D}$ sodium salt $54.3 \%$ SP @ (20+543) g a.i/ha with adjuvant @ $625 \mathrm{ml} / \mathrm{ha}\left(\mathrm{T}_{4}\right)$, bispyribac sodium 2\%+ 2,4-D sodium salt 54.3\% SP @ (25+678.75) g a.i/ha with adjuvant @ $625 \mathrm{ml} / \mathrm{ha}\left(\mathrm{T}_{5}\right)$, bispyribac sodium 2\%+2,4-D sodium salt $54.3 \%$ SP @ $(30+814.5)$ g a.i/ha with adjuvant@625 ml/ha( $\left.\mathrm{T}_{6}\right)$, bispyribac sodium $10 \%$ SC @ $20 \mathrm{~g}$ a.i/ha $\left(\mathrm{T}_{7}\right), 2,4-\mathrm{D}$ Ethyl ester $38 \%$ EC @ 850g a.i/ha $\left(\mathrm{T}_{8}\right)$ and penoxsulam $21.7 \%$ SC @ $22.5 \mathrm{~g}$ a.i/ha $\left(\mathrm{T}_{9}\right)$. These were compared with hand weeding twice at 15 and 45 DAT $\left(\mathrm{T}_{11}\right)$, farmers practice (pendimethalin $38.7 \% \mathrm{CS}$ as $\mathrm{PE} f b$ bispyribac sodium $10 \% \mathrm{SC})\left(\mathrm{T}_{10}\right)$ and weedy check $\left(\mathrm{T}_{12}\right)$.The experimental field was ploughed twice with disc harrow and tractor drawn cultivator followed by puddling with rotovator and later levelled uniformly. The seed rate of $25 \mathrm{~kg} \mathrm{ha}^{-1}$ was used for establishment methods. The most popular and predominant variety BPT-5204 was planted at a spacing of $20 \mathrm{~cm} \mathrm{X} 10 \mathrm{~cm}$ at the seedling age of 30 days, the recommended dose of 
fertilizer 150:75:75 kg N, $\mathrm{P}_{2} \mathrm{O}_{5}$ and $\mathrm{K}_{2} \mathrm{O} \mathrm{ha}^{-1}$ along with $20 \mathrm{~kg} \mathrm{ZnSO}_{4}$ was applied. The half of the nitrogen $\left(75 \mathrm{~kg} \mathrm{~N} \mathrm{ha}{ }^{-1}\right)$ and full quantity of phosphoric (75 $\left.\mathrm{kg} \mathrm{P}_{2} \mathrm{O}_{5}\right)$ and potassic $\left(75 \mathrm{~kg} \mathrm{~K}_{2} \mathrm{O}\right)$ fertilizer were given at the time of transplanting and remaining quantity of nitrogen was given in two equal splits at tillering and panicle stage of the crop, respectively.

The experimental soil was medium black clay in texture, moderately alkaline in reaction $(\mathrm{pH}$ 8.12) with an electrical conductivity of 0.46 $\mathrm{dSm}^{-1}$, low in organic carbon $(0.58 \%)$ and available nitrogen $\left(203.71 \mathrm{~kg} \mathrm{ha}^{-1}\right)$, high in available phosphorus (71.27 $\mathrm{kg} \mathrm{ha}^{-1}$ ) and high in exchangeable potassium (364.01 $\left.\mathrm{kg} \mathrm{ha}^{-1}\right)$. The gross and net plot sizes were 5.0 $\mathrm{m} \mathrm{X} 4.0 \mathrm{~m}$ and $4.2 \mathrm{~m} \mathrm{X} 3.4 \mathrm{~m}$, respectively.

\section{Results and Discussion}

\section{Number of tillers $\mathbf{m}^{-2}$}

Number of tillers $\mathrm{m}^{-2}$ was maximum under hand weeding twice at 15 and 45 DAT (323.00). This was obviously because of efficient control of weeds which in turn helped in better uptake of nutrients and this led to formation of more number of tillers as compared to unweeded control (212.67), where the crop had to face more competition stress by weeds, resulting in lower number of tillers (Table 1).

This was on par with pendimethalin $38.7 \%$ CS @ $680 \mathrm{~g}$ a.i/ha as PE $f b$ bispyribac sodium 10\% SC @ 25 g a.i/ha (320.00) probably due to reduced competition from weeds at early stages of crop growth with a better weed control efficiency and without injury to the crop providing ideal environment for rice plants to have more pronounced tillers number. Findings of Akabar et al., (2011) are in support of these observations.

\section{Leaf Area Index (LAI)}

Hand weeding recorded significantly higher (1.40) LAI which was followed by bispyribac sodium 2\% + 2,4-D sodium salt 54.3\% SP @ $(25+678.75) \mathrm{g}$ a.i/ha with adjuvant @ 625 $\mathrm{ml} / \mathrm{ha}$ (1.06) but remained on par with pendimethalin 38.7\% CS @ $680 \mathrm{~g} \mathrm{a.i/ha}$ as PE $f b$ bispyribac sodium 10\% SC @ $25 \mathrm{~g}$ a.i/ha (1.16) (Table 1).This was attributed to the availability of optimum growth factors for enhancing the assimilatory surface area. The weed free environment provides more chance for leaves to expand and cover the area by its canopy in an appreciable manner.

\section{Total dry matter production (g plant ${ }^{-1}$ )}

Significantly higher total dry matter production was recorded under hand weeding twice at 15 and 45 DAT (68.71 $\mathrm{g} \mathrm{plant}^{-1}$ ) as compared to weedy check (40.92 $\mathrm{g} \mathrm{plant}^{-1}$ ) (Table 1). Among the herbicide, pendimethalin $38.7 \%$ CS @ $680 \mathrm{~g}$ a.i/ha as PE $f b$ bispyribac sodium 10\% SC @ $25 \mathrm{~g}$ a.i/ha recorded higher dry weight (66.83 g plant $^{-1}$ ) and was on par with bispyribac sodium 2\% + 2,4-D sodium salt 54.3\% SP @ $(25+678.75) \mathrm{g}$ a.i/ha with adjuvant @ 625 $\mathrm{ml} / \mathrm{ha}\left(63.31 \mathrm{~g} \mathrm{plant}^{-1}\right)$. This might be due to weed free environment helps the crop for better plant dry matter production. Similar view was expressed by Uma et al., (2014).

\section{Yield attributing characters as influenced} by different weed management practices

Weed management practices had significant influence on panicle length, number of panicles $\mathrm{m}^{-2}$, grains panicle ${ }^{-1}$ and test weight (Table 2). Hand weeding twice at 15 and 45 DAT recorded the highest panicle length $(19.80 \mathrm{~cm})$, number of panicles $\mathrm{m}^{-2}(323.00)$, grains panicle ${ }^{-1}$ (231.00) and test weight $(21.17 \mathrm{~g})$ which was on par with pendimethalin 38.7\% CS @ 680g a.i/ha as PE 
fb bispyribac sodium 10\% SC @ $25 \mathrm{~g} \mathrm{a.i/ha}$ $(19.2 \mathrm{~cm}, \quad 317.00,221$ and $18.89 \mathrm{~g}$, respectively) followed by bispyribac sodium $2 \%+2,4-\mathrm{D}$ sodium salt $54.3 \%$ SP @ $(25+678.75) \mathrm{g}$ a.i/ha with adjuvant @ 625 $\mathrm{ml} / \mathrm{ha}(18.8 \mathrm{~cm}, 312.00,211.00$ and $18.78 \mathrm{~g}$, respectively). In contrast, unweeded control recorded significantly lower panicle length $(12.00 \mathrm{~cm}, 209.00,122.00$ and $17.02 \mathrm{~g}$, respectively).

Appreciably lowest effective tiller and panicle length were noted under weedy check plots. This was because of heavy weed competition which hampered the supply of growth resources below the demand resulting in poor vegetative growth and reduced assimilatory area per unit of ground area. These results are in accordance with the findings of Patra et al., (2016).Significantly higher number of grains per panicle and test weight were noted under hand weeding twice and pendimethalin $38.7 \%$ CS @ $680 \mathrm{~g}$ a.i/ha as PE $f b$ bispyribac sodium 10\% SC @ $25 \mathrm{~g}$ a.i/ha. This was due to better suppression of weeds and the weed free environment to the crop, gave more room for formation and development of grains which led to register the superior values of total and sound grains per panicle under aforesaid treatments. Similar findings were also reported by Kumar etal. (2010).

\section{Grain and straw yields}

The highest grain and straw yield was obtained under hand weeding twice (5415 and $5783 \mathrm{~kg} \mathrm{ha}^{-1}$ ), which was on par with pendimethalin 38.7\% CS @680 g a.i/ha as PE fbbispyribac sodium 10\% SC @ $25 \mathrm{~g}$ a.i/ha (4990 and $5433 \mathrm{~kg} \mathrm{ha}^{-1}$ ) and bispyribac sodium 2\% + 2,4-D sodium salt 54.3\% SP @ $(25+678.75)$ g a.i/ha with adjuvant @ 625 $\mathrm{ml} / \mathrm{ha}\left(4922\right.$ and $5372 \mathrm{~kg} \mathrm{ha}^{-1}$ ) as compared to weedy check (2137 and $2713 \mathrm{~kg} \mathrm{ha}^{-1}$ ) (Table 3). The enhanced yields under these treatments was because of elimination of weeds which helped in enhancing the availability of nutrients, space, sunlight and water resulting in better growth and development of crop plants. This caused better yield attributing characters and accumulation of more dry matter in leaves, stem and ultimately the highest yields. These results are in collaboration with the findings of Singh et al., (2017).

\section{Economics}

The economics of crops was measured in terms of gross return, net return and $\mathrm{B}$ : $\mathrm{C}$ ratio as shown in Table3. Data recorded under different components revealed that gross return was increased with increasing biological yield of transplanted rice obtained under different treatments. Hand weeding at 15 and 45 DAT fetched significantly higher gross returns (Rs. $112030 \mathrm{ha}^{-1}$ ) over weedy check (Rs. $45427 \mathrm{ha}^{-1}$ ) and was on par with pendimethalin $38.7 \%$ CS @ $680 \mathrm{~g} \mathrm{a}$.i/ha as PE $f b$ bispyribac sodium 10\% SC @ $25 \mathrm{~g}$ a.i/ha(Rs. $105235 \mathrm{ha}^{-1}$ ) followed by bispyribac sodium $2 \%+2,4-\mathrm{D}$ sodium salt $54.3 \%$ SP @ (25+678.75) g a.i/ha with adjuvant@625 ml/ha (Rs.103819 ha ${ }^{-1}$ ) and bispyribac sodium $2 \%+2,4-\mathrm{D}$ sodium salt $54.3 \%$ SP @ (20+543) g a.i/ha with adjuvant @ $625 \mathrm{ml} / \mathrm{ha}$ (Rs. $96437 \mathrm{ha}^{-1}$ ). The values of gross returns was minimum in weedy check plot and maximum under hand weeding twice, these variations were due to differences in economical yield (grain and straw) under the treatments.

The highest net returns was recorded with hand weeding twice at 15 and 45 DAT (Rs. $66715 \mathrm{ha}^{-1}$ ) than weedy check (Rs. $7612 \mathrm{ha}^{-1}$ ) and was on par with bispyribac sodium $2 \%+$ 2,4-D sodium salt 54.3\% SP @ (25+678.75) g a.i/ha with adjuvant @ 625 ml/ha (RS. 64129 $\mathrm{ha}^{-1}$ ) followed by pendimethalin 38.7\% CS @ $680 \mathrm{~g}$ a.i/ha as PE $f b$ bispyribac sodium $10 \%$ SC @ $25 \mathrm{~g} \mathrm{a.i/ha} \mathrm{(Rs.} 63900 \mathrm{ha}^{-1}$ ). 
Table.1 Plant height, number of tillers per square meter, Leaf Area Index and total dry matter production as influenced by weed control treatments in transplanted rice

\begin{tabular}{|c|c|c|c|}
\hline Treatment & $\begin{array}{c}\text { Number } \\
\text { of tillers } \\
\mathbf{m}^{-2}\end{array}$ & $\begin{array}{l}\text { Leaf } \\
\text { Area } \\
\text { Index }\end{array}$ & $\begin{array}{c}\text { Total dry matter } \\
\text { production } \\
\left(\text { g plant }^{-1}\right)\end{array}$ \\
\hline $\mathrm{T}_{1}$ - Bispyribac sodium 2\%+2,4-D sodium salt 54.3\% SP @ (20+543) g a.i/ha & 294.00 & 0.54 & 51.48 \\
\hline $\begin{array}{l}\mathrm{T}_{2} \text {-Bispyribac sodium } 2 \%+2,4-\mathrm{D} \text { sodium salt } 54.3 \% \text { SP @ }(25+678.75) \mathrm{g} \\
\text { a.i/ha }\end{array}$ & 298.00 & 0.58 & 52.41 \\
\hline $\mathrm{T}_{3}$-Bispyribac sodium 2\%+2,4-D sodium salt 54.3\% SP @ $(30+814.5)$ g a.i/ha & 292.00 & 0.53 & 50.79 \\
\hline $\begin{array}{l}\mathrm{T}_{4} \text {-Bispyribac sodium } 2 \%+2,4-D \text { sodium salt } 54.3 \% \mathrm{SP} @(20+543) \mathrm{g} \text { a.i/ha } \\
\text { with adjuvant } @ 625 \mathrm{ml} / \mathrm{ha}\end{array}$ & 301.33 & 0.85 & 56.32 \\
\hline $\begin{array}{l}\mathrm{T}_{5-} \text { Bispyribac sodium } 2 \%+2,4-\mathrm{D} \text { sodium salt } 54.3 \% \text { SP @ }(25+678.75) \mathrm{g} \\
\text { a.i/ha with adjuvant @ } 625 \mathrm{ml} / \mathrm{ha}\end{array}$ & 315.00 & 1.06 & 63.31 \\
\hline $\begin{array}{l}\text { T }_{6} \text {-Bispyribac sodium } 2 \%+2,4-D \text { sodium salt } 54.3 \% \text { SP @ }(30+814.5) \mathrm{g} \\
\text { a.i/ha with adjuvant @ } 625 \mathrm{ml} / \mathrm{ha}\end{array}$ & 302.33 & 0.81 & 56.32 \\
\hline T $_{7}$-Bispyribac sodium 10 \% SC @ 20 g a.i/ha & 275.00 & 0.59 & 48.24 \\
\hline T/ 2,4-D Ethyl ester 38\% EC @ 850 ga.i/ha & 272.33 & 0.56 & 47.14 \\
\hline T9-Penoxsulam $21.7 \%$ SC @ $22.5 \mathrm{~g}$ a.i/ha & 270.00 & 0.54 & 46.45 \\
\hline $\begin{array}{l}\text { T10- }_{10} \text { Pendimethalin } 38.7 \% \text { CS @ } 680 \mathrm{~g} \text { a.i/ha as PE } f b \text { Bispyribac sodium } 10 \\
\% \text { SC @ } 25 \mathrm{~g} \mathrm{a.i/ha}\end{array}$ & 320.00 & 1.16 & 66.83 \\
\hline$T_{11^{-}}$Weed free check (Hand weeding at 15 and 45 DAT) & 323.00 & 1.40 & 68.71 \\
\hline$T_{12}-$ Weedy check (Untreated control) & 212.67 & 0.24 & 40.92 \\
\hline S.Em \pm & 1.53 & 0.06 & 1.76 \\
\hline C.D. $=(0.05)$ & 4.48 & 0.16 & 5.17 \\
\hline
\end{tabular}


Table.2 Panicle length, number of panicles per sq.m, number of grains per panicle and test weight as influenced by weed control treatments in transplanted rice

\begin{tabular}{|c|c|c|c|c|}
\hline Treatment & $\begin{array}{c}\text { Panicle } \\
\text { length } \\
\text { (cm) }\end{array}$ & $\begin{array}{c}\text { No. of } \\
\text { panicles } \\
\mathbf{m}^{-2}\end{array}$ & $\begin{array}{c}\text { No. of } \\
\text { grains } \\
\text { panicle }^{-1}\end{array}$ & $\begin{array}{c}\text { Test } \\
\text { weight } \\
\text { (g) }\end{array}$ \\
\hline $\mathrm{T}_{1}$ - Bispyribac sodium $2 \%+2,4-\mathrm{D}$ sodium salt $54.3 \%$ SP @ $(20+543) \mathrm{g}$ a.i/ha & 17.5 & 291 & 175 & 18.24 \\
\hline $\mathrm{T}_{2}$-Bispyribac sodium $2 \%+2,4-\mathrm{D}$ sodium salt 54.3\% SP @ $(25+678.75) \mathrm{g}$ a.i/ha & 17.6 & 295 & 182 & 18.57 \\
\hline $\mathrm{T}_{3}$-Bispyribac sodium 2\%+2,4-D sodium salt 54.3\% SP @ $(30+814.5) \mathrm{g}$ a.i/ha & 17.2 & 289 & 170 & 18.09 \\
\hline $\begin{array}{l}\text { T}_{4} \text {-Bispyribac sodium } 2 \%+2,4-D \text { sodium salt } 54.3 \% \text { SP @ }(20+543) \mathrm{g} \text { a.i/ha } \\
\text { with adjuvant @ } 625 \mathrm{ml} / \mathrm{ha}\end{array}$ & 18.3 & 298 & 208 & 18.75 \\
\hline $\begin{array}{l}\text { T }_{5-} \text { Bispyribac sodium } 2 \%+2,4-D \text { sodium salt } 54.3 \% \text { SP @ }(25+678.75) \mathrm{g} \text { a.i/ha } \\
\text { with adjuvant @ } 625 \mathrm{ml} / \mathrm{ha}\end{array}$ & 18.8 & 312 & 211 & 18.78 \\
\hline $\begin{array}{l}\mathrm{T}_{6} \text {-Bispyribac sodium } 2 \%+2,4-\mathrm{D} \text { sodium salt } 54.3 \% \mathrm{SP} @(30+814.5) \mathrm{g} \text { a.i/ha } \\
\text { with adjuvant @ } 625 \mathrm{ml} / \mathrm{ha}\end{array}$ & 18.0 & 299 & 199 & 18.56 \\
\hline T-Bispyribac sodium $10 \%$ SC @ $20 \mathrm{~g}$ a.i/ha & 16.4 & 272 & 160 & 17.65 \\
\hline 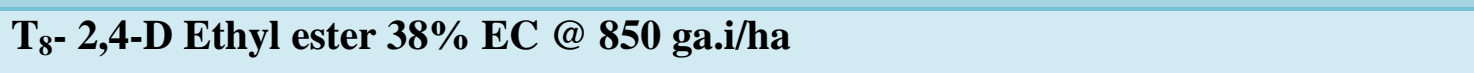 & 16.3 & 269 & 158 & 17.58 \\
\hline T9-Penoxsulam $21.7 \%$ SC @ $22.5 \mathrm{~g}$ a.i/ha & 16.3 & 267 & 152 & 17.43 \\
\hline $\begin{array}{l}\mathrm{T}_{10} \text { - Pendimethalin } 38.7 \% \text { CS @ } 680 \mathrm{~g} \text { a.i/ha as PE } f b \text { Bispyribac sodium } 10 \% \\
\text { SC @ } 25 \mathrm{~g} \text { a.i/ha }\end{array}$ & 19.2 & 317 & 221 & 18.89 \\
\hline 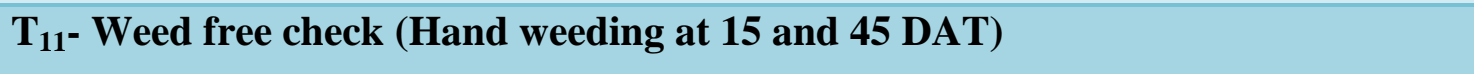 & 19.8 & 323 & 231 & 21.17 \\
\hline$T_{12-}$ Weedy check (Untreated control) & 12.0 & 209 & 122 & 17.02 \\
\hline S.Em \pm & 0.84 & 2.15 & 3.43 & 0.38 \\
\hline C.D. $=(0.05)$ & 4.47 & 6.30 & 10.07 & 1.10 \\
\hline
\end{tabular}


Table.3 Grain yield, straw yield, cost of cultivation, gross returns, net returns and B:C ratio of rice as influenced by different weed management practices

\begin{tabular}{|c|c|c|c|c|c|c|}
\hline Treatment & $\begin{array}{c}\text { Grain } \\
\text { yield } \\
\text { (kg/ha) }\end{array}$ & $\begin{array}{c}\text { Straw } \\
\text { yield } \\
\text { (kg/ha) }\end{array}$ & $\begin{array}{c}\text { Cost of } \\
\text { cultivation } \\
\text { (Rs./ha) }\end{array}$ & $\begin{array}{c}\text { Gross } \\
\text { returns } \\
\text { (Rs./ha) }\end{array}$ & $\begin{array}{l}\text { Net } \\
\text { returns } \\
\text { (Rs./ha) }\end{array}$ & B:C \\
\hline $\begin{array}{l}T_{1} \text { - Bispyribac sodium } 2 \%+2,4-D \text { sodium salt } 54.3 \% \text { SP @ }(20+543) g \\
\text { a.i/ha }\end{array}$ & 4260 & 4777 & 39215 & 89984 & 50769 & 2.29 \\
\hline $\begin{array}{l}\mathrm{T}_{2} \text {-Bispyribac sodium } 2 \%+2,4-\mathrm{D} \text { sodium salt } 54.3 \% \text { SP @ }(25+678.75) \mathrm{g} \\
\text { a.i/ha }\end{array}$ & 4317 & 4816 & 39565 & 91163 & 51598 & 2.30 \\
\hline $\begin{array}{l}\mathrm{T}_{3} \text {-Bispyribac sodium } 2 \%+2,4 \text {-D sodium salt } 54.3 \% \text { SP @ }(30+814.5) \mathrm{g} \\
\text { a.i/ha }\end{array}$ & 4254 & 4774 & 39915 & 89854 & 49939 & 2.25 \\
\hline $\begin{array}{l}\text { T4-Bispyribac sodium } 2 \%+2,4-D \text { sodium salt } 54.3 \% \text { SP @ }(20+543) \mathrm{g} \\
\text { a.i/ha with adjuvant } @ 625 \mathrm{ml} / \mathrm{ha}\end{array}$ & 4569 & 5044 & 39340 & 96437 & 57097 & 2.45 \\
\hline $\begin{array}{l}\mathrm{T}_{5^{-}} \text {Bispyribac sodium } 2 \%+2,4-\mathrm{D} \text { sodium salt } 54.3 \% \mathrm{SP} @(25+678.75) \mathrm{g} \\
\text { a.i/ha with adjuvant @ } 625 \mathrm{ml} / \mathrm{ha}\end{array}$ & 4922 & 5372 & 39690 & 103819 & 64129 & 2.62 \\
\hline $\begin{array}{l}\text { T6-Bispyribac sodium } 2 \%+2,4-D \text { sodium salt } 54.3 \% \text { SP @ }(30+814.5) \mathrm{g} \\
\text { a.i/ha with adjuvant } @ 625 \mathrm{ml} / \mathrm{ha}\end{array}$ & 4524 & 5011 & 40040 & 95504 & 55464 & 2.39 \\
\hline T & 3624 & 4155 & 38915 & 76642 & 37727 & 1.97 \\
\hline T. 2,4-D Ethyl ester 38\% EC @ 850 ga.i/ha & 3468 & 3994 & 38940 & 73354 & 34414 & 1.88 \\
\hline T9-Penoxsulam $21.7 \%$ SC @ 22.5 g a.i/ha & 3559 & 4086 & 39595 & 75266 & 35671 & 1.90 \\
\hline $\begin{array}{l}\text { T }_{10-} \text { Pendimethalin } 38.7 \% \text { CS @ } 680 \mathrm{~g} \text { a.i/ha as PE } f b \text { Bispyribac sodium } \\
10 \% \text { SC @ } 25 \mathrm{~g} \text { a.i/ha }\end{array}$ & 4990 & 5433 & 41335 & 105235 & 63900 & 2.55 \\
\hline$T_{11^{-}}$Weed free check (Hand weeding at 15 and 45 DAT) & 5415 & 5783 & 45315 & 112030 & 66715 & 2.47 \\
\hline $\mathbf{T}_{12-}$ Weedy check (Untreated control) & 2137 & 2713 & 37815 & 45427 & 7612 & 1.20 \\
\hline S.Em \pm & 137 & 185 & & 2796 & & 0.07 \\
\hline C.D. $=(0.05)$ & 403 & 544 & & 8201 & & 0.21 \\
\hline
\end{tabular}


The maximum net returns under these treatments were due to higher grain and straw yields. Similar findings were also reported by Uma et al., (2014).

Bispyribac sodium $2 \%+2,4-\mathrm{D}$ sodium salt $54.3 \%$ SP @ $(25+678.75)$ g a.i/ha with adjuvant@625 ml/ha recorded significantly higher $\mathrm{B}: \mathrm{C}$ ratio (2.62) over unwedded control (1.20) and on par with pendimethalin $38.7 \%$ CS @ $680 \mathrm{~g}$ a.i/ha as PE $f b$ bispyribac sodium 10\% SC @ $25 \mathrm{~g}$ a.i/ha (2.55), weed free control (2.47), bispyribac sodium $2 \%+$ 2,4-D sodium salt 54.3\% SP @ (20+543) g a.i/ha with adjuvant @ $625 \mathrm{ml} / \mathrm{ha}$ (2.45). Though some herbicides recorded with higher grain yield and gross returns, the net returns observed was less than that of hand weeding which was due to the high cost of herbicides. These findings are in parallel with the previous results Singh etal. (2017).

It was concluded that, hand weeding twice at 15 and 45 DAT recorded significantly higher growth and yield attributing characters, gross returns and net returns as compared to other treatment which was on par with pendimethalin 38.7\% CS @ $680 \mathrm{~g}$ a.i/ha as PE $f b$ bispyribac sodium 10\% SC @ $25 \mathrm{~g}$ a.i/ha where as significantly higher B:C recorded with bispyribac sodium $2 \%+2,4-\mathrm{D}$ sodium salt 54.3\% SP @ (25+678.75) g a.i/ha with adjuvant @625 ml/ha.

\section{References}

Akabar, N., Ali and Ehsanullah., 2011, Weed management improves yield and quality of direct seeded rice. Australian J. Crop Sci., 5(6): 688-694.

Anonymous, 2018, Agricultural statistics at a glance, Government of India Ministry of agriculture \& Farmers Welfare Department of Agriculture, Cooperation \& Farmers Welfare Directorate of Economics and Statistics: 105.

Kumar, J., Singh, D., Puniya, R. and Pandey, P. C., 2010, Effect of weed management practices on nutrient uptake by direct seeded rice. Oryza, 47(4): 291-294.

Patra, A. K., Halder, J. and Mishra, M. M., 2016, Chemical weed control in transplanted rice in Hirakud command area of Orissa. Indian J. Weed Sci., 43(3\& 4): 175-177

Singh, A., Nandal, D. P. and S. S., Punia, 2017, Bio-Efficacy of sequential application of herbicides on weeds and yield in direct seeded rice (Oryza sativa). Int. J. Curr. Microbiol. App. Sci., 6(4): 900-905.

Uma, G., Ramana, M., Venkata, Reddy, A., Pratap, K. and Prakash. T. R., 2014, Evalution of low dose herbicides in transplanted rice. Int. J. Applied Biology Pharmaceutical Tech., 5: 96-101.

\section{How to cite this article:}

Tejaswini, M., A. S. Halepyati, S. Manoranjan, B. M. Chittapur and Ananda, N. 2020. Effect of Post Emergence Herbicide on Growth, Yield and Economics of Transplanted Rice (Oryza sativa L.). Int.J.Curr.Microbiol.App.Sci. 9(07): 63-70.

doi: https://doi.org/10.20546/ijcmas.2020.907.007 